\title{
Women's role model in Banyuwangi in preparing brilliant generations: in the economic perspective
}

\author{
Farida Wahyu Ningtyias ${ }^{1}$, Taufik Kurrohman ${ }^{2}$, and Andriana ${ }^{3}$ \\ ${ }^{1}$ Faculty of public health; University of Jember \\ ${ }^{2}$ Faculty of economics and business; University of Jember \\ ${ }^{3}$ Faculty of economics and business; University of Jember
}

\begin{abstract}
This study aims to reveal the role of women, especially mothers, in supporting the 1000 HPK program in an economic perspective in Banyuwangi (tribe of "Osing"). The women are required to survive in conditions of economic limitations, on the other hand, they are expected to meet the nutritional needs of mothers and babies. This study uses a qualitative method with research samples of mothers in Banyuwangi subdistrict. Data retrieval is done by in-depth interviews with pregnant, lactating mothers, and mothers who have children under five. The results of this study found a local savings model coordinated by "posyandu" cadre groups to help solve financial problems in the society. This savings model is called "arisan". Furthermore, financial needs from the early pregnancy to childbirth and toddlers are quite high. This is because they have to do some traditional rituals, of course, it requires a fee, during pregnancy to toddler. The "arisan" is one of the solutions made by women to solve financial problems in relation to nutrient intake which indirectly impacts the bright generation.
\end{abstract}

\section{Introduction}

Personal financial management (financial planning and control) is one form of application of financial management. Financial management is not only important for the company, but knowledge of financial management is also important to apply to the family or household of each individual. Not only companies are absolutely responsible for managing their finances well, their families and individuals must be adept at handling their finances so that their income and expenses can be adjusted in balance, planning personal and family finances is absolutely necessary so that the journey of the next life is more comfortable (Yuliati, 2016) [1]. Lack of knowledge about financial planning becomes a serious problem for the Indonesian people (Mendari and Kewal, 2013) [2].

Accordingly, the majority of Indonesians are threatened with poverty in old age. Indonesia has a number of households or residents already married in 2014 reaching

\footnotetext{
* Corresponding author: farida.fkm@unej.ac.id
} 
64,771,600 households. The number of these households experienced an increase of 730,400 households from 2013 [3]. The increasing population of Indonesia who are married but not followed by good financial management and do not have reserve funds, then indirectly the number of poverty at the old age will increase.

On the other hand, whether or not a new brilliant generation depending on nutritional intake from pregnancy to a certain time. This growth and development require nutritional intake from the mother, both consumed by the mother and from the mobilization of maternal savings. If the supply of nutrition from mother to baby is lacking, the baby will make adjustments, because the baby is plastic (easy to adjust). These adjustments can be through a reduction in the number of cells and a smaller size of organs and body so that they are in line with the limited nutritional intake. Unfortunately, once it changes, it is permanent, or if the improvement of nutrition is done after passing through the first thousand years of life, then the repair effect is small, on the contrary, if it is done during the $1000 \mathrm{HPK}$, especially in the womb, the improvement effect is meaningful.

This permanent change is what causes long-term problems. This situation turns out not only to be intergenerational (from mother to child) but trans-generational (from grandmother to grandchild). So the estimated impact has a period of 100 years, meaning that the risk comes from problems that occurred about 100 years ago, and the impact will be sustained in the next 100 years. Problems related to nutritional intake in 1000 HPK originated from errors in managing family finances.

Without good financial planning, people will find it difficult to allocate their income for spending on good nutrition. The financial planning model can be obtained by taking good habits that are often carried out by certain communities and cultures, one of which is the tribal society $[4,5]$. The cultural values of the tribe of "Osing" include a culture of mutual cooperation and gathering in the culture of the "tilik dusun" [6] which is accompanied by the activities of the community gathering. In the forum usually, women will exchange information and learn to improve their level of financial literacy. This "arisan" activity is carried out by allocating the funds at the beginning to fulfill their future needs and many more activities that can be applied to plan their finances. With this approach to cultural aspects, the financial planning and financing model at 1000 HPK will be very economical, effective and efficient in accordance with their needs and capabilities.

\section{Research methods}

The approach in this study is qualitative. As for qualitative using phenomenological methods. Referring to the opinion of Lexy [7], who said that qualitative research is research that uses a naturalistic approach to find and find understanding or understanding of phenomena in a special context. In this study, phenomenology is used to describe and explain how actors understand the cultural meaning of women in managing their family finances related to family nutritional intake. Furthermore, in the settings in this study also interviewed mothers in choosing a food menu under conditions of limited funds. Data and information used are valid and accurate, to obtain in-depth interviews with informants who are used as sources of information [8]. While the informants selected were informants who understood the tribe of "Osing", namely for pregnant, lactating mothers, and mothers who had children under five who were members of the society.

\subsection{Techniques analysis}

The study was carried out in two stages, where the first phase will be carried out in the first year of research. The analysis that will be carried out in the stages: 


\section{Nutritional status}

To determine the nutritional status, the researcher will divide into three segments, namely the determination of the nutritional status of the toddler group, determination of the nutritional status of the mother group, and determination of the nutritional status of other family members. In determining this nutritional status laboratory analysis and measurement will be carried out directly to the respondent. The result of this analysis is the knowledge of nutritional status along with the nutritional track record of each segment.

\section{Determination of Nutritional Needs}

After the nutritional status is known, the next step is to analyze nutritional needs for three periods: pre-pregnancy, pregnancy and post-pregnancy period to 2 years of age. In determining this nutritional need, the ideal nutritional needs and minimal nutritional needs will be calculated and analyzed. From each group of respondents, it is expected that the types of nutritional needs that exist today and how to achieve the ideal nutrition is needed, how many elements of nutrition.

\section{Determination of shopping needs}

The next step is determining shopping needs. After the nutritional needs are identified, the next step is to calculate the total nutritional needs needed by each group. In addition, in determining shopping needs, there will also be an optimization of the existing local food sources with several alternative shopping scenarios. Wrong

\section{Determination of income sources}

In this analysis, the researcher will calculate the analysis of income sources that come from regular sources of income and non-regular ones. In addition, it will also analyze the cost volume of profit from each source of income.

Identification of socio-cultural aspects

In this stage, institutional aspects, identification of social activities, and culture that become habits in the society will be identified.

\section{Analysis of Community Culture Community Culture}

Analysis will be identified by local cultural characters by adopting the principles adopted in the community. In this study, "Osing" culture as a majority culture of Banyuwangi people has the slogan "Laros Jenggirat" which means the people of "Osing" rise. The word rises can mean encouragement when working on his work or when his business starts sluggishly. In this cultural analysis, Focus Group Discussion will be conducted with cultural figures and business figures in the village.

\subsection{Validity of data}

To test the validity of the data obtained, data triangulation techniques were used. The type of data triangulation used is the triangulation of sources that is comparing and checking the degree of trust of information obtained through different time and tools in qualitative.

\section{Result and discussion}

\subsection{Nutritional status of the "Osing" community}

The health status of respondents is mostly normal. This is illustrated in Table 1: 
Table 1. "Osing" society nutritional status nutritional.

\begin{tabular}{|c|c|c|c|c|c|}
\hline Status & $\mathrm{n}$ & $\%$ & Status & $\mathrm{n}$ & $\%$ \\
\hline Pregnant Women (BMI) & & & Adult Men & & \\
\hline - Obesity & 2 & 9.09 & - Obesity & 1 & 12.5 \\
\hline - $\quad$ Overweight & 2 & 9.09 & - Overweight & 3 & 37.5 \\
\hline - $\quad$ Normal & 14 & 63.63 & - $\quad$ Normal & 4 & 50 \\
\hline - $\quad$ Underweight & 4 & 18.19 & - Underweight & - & - \\
\hline Total & 22 & 100 & Total & 8 & 100 \\
\hline WUS (Age Women Fertile) & & & Toddlers & & \\
\hline - Obesity & 4 & 18.19 & - Nutritional Good & 13 & 92.9 \\
\hline - $\quad$ Overweight & 2 & 9.09 & - $\quad$ Poor Nutrition & 1 & 7.1 \\
\hline - $\quad$ Normal & 14 & 63.63 & Total & 14 & 100 \\
\hline - $\quad$ Underweight & 2 & 9.09 & & & \\
\hline Total & 22 & 100 & & & \\
\hline
\end{tabular}

Table 1 shows the nutritional status of respondents in the society. Most groups of respondents have normal nutritional status. But what needs attention in the group of pregnant women is 4 people who have underweight nutritional status. Pregnant women who suffer from KEK have a risk of sudden maternal death in the perinatal period or the risk of giving birth to babies with low birth weight (LBW). The causes of nutritional problems in pregnant women are knowledge, nutritional intake (food consumption), education, infectious diseases (level of health), employment, and economic status. A person with a high economy will most likely need the nutrients needed and there is a pregnancy check to make maternal nutrition more monitored [9].

In addition, there are still pregnant women who experienced a rapid increase in BB so that they have overweight and obesity nutritional status of $9.09 \%$. Weight gain recommended for pregnant women is affected by maternal status before pregnancy. Women who have excessive weight before pregnancy, weight gain is recommended should be smaller than mothers with ideal body weight, which is between $12.5-17.5$ kilograms this is because it will have a risk to become gestational diabetes (increase in blood sugar levels because the existence of a pregnancy process or the occurrence of preeclampsia (pregnancy poisoning where there is an increase in blood pressure). The recommended weight gain during pregnancy is $14-20 \mathrm{~kg}$ from the weight of pregnant women who previously had normal weight because excessive weight gain will affect pregnancy and children to be born later. If there is a lack of nutrition, it will have an impact on fetal growth in the womb such as low birth weight (LBW) and pregnancy disorders will occur [10].

\subsection{The level of consumption by the society}

Most of the respondents' consumption level is in a severe deficit, there is no balance between macronutrients consumed by respondents. The balance of food consumption will occur when consumption of food sources of carbohydrates, fats, and proteins in accordance with the recommended nutritional needs. This can be seen in Table 2: 
Table 2. Consumption community "Osing".

\begin{tabular}{|c|c|c|c|c|c|}
\hline $\begin{array}{l}\text { Energy Consumption } \\
\text { Levels }\end{array}$ & & $\mathrm{n} \%$ & Fat Consumption Level & & \\
\hline$\bullet \quad$ Over & 2 & 4.44 & - $\quad$ More & 4 & 8.9 \\
\hline - Good & 6 & 13.3 & - Good & & 24.4 \\
\hline - $\quad$ Enough & - & & - $\quad$ Sufficient & - & \\
\hline - $\quad$ Less & - & & - $\quad$ Less & - & \\
\hline - $\quad$ mild deficit & 3 & 6.67 & - $\quad$ Mild Deficit & 3 & 6.67 \\
\hline - Deficit Average & 3 & 6.67 & $\begin{array}{ll}\text { - } & \text { Moderate } \\
& \text { Deficit } \\
\end{array}$ & 3 & 6.67 \\
\hline - $\quad$ Deficit Weight & 31 & $\begin{array}{c}68 \\
9\end{array}$ & - Weight Deficit & 24 & 53.3 \\
\hline Total & 45 & 100 & Total & 45 & 100 \\
\hline $\begin{array}{l}\text { Carbohydrate } \\
\text { Consumption Levels }\end{array}$ & & & Protein Consumption & & \\
\hline - More & 3 & 6.67 & - $\quad$ More & 6 & 13.3 \\
\hline - Good & 4 & 8.9 & - Good & 7 & 15.6 \\
\hline - $\quad$ Fair & - & & - $\quad$ Enough & - & \\
\hline - $\quad$ Less & - & & - $\quad$ Less & - & \\
\hline - $\quad$ Mild Deficit & 2 & 4.44 & - $\quad$ Mild Deficit & 4 & 8.9 \\
\hline - $\quad$ Medium Deficit & 2 & 4.44 & - $\quad$ Medium Deficit & 6 & 13.3 \\
\hline • Weight Deficit & 34 & 75.6 & • Weight Deficit & 22 & 48.9 \\
\hline Total & 45 & 100 & Total & & 100 \\
\hline
\end{tabular}

This can occur due to the lack of variety in food consumption and the amount is also inadequate. For adults, the imbalance in consumption of foods that tend to be less will affect their health and performance. This if it is associated with nutritional status, there are many respondents who have underweight nutritional status, and will affect their work productivity. Whereas for pregnant women and toddlers will affect their pregnancy and child growth. Children under five who have poor parenting, one of which can be seen from the consumption of food will have a lack of nutritional status [11].

\subsection{Strategies to overcome nutritional problems within the limited financial capacity}

Issues about family nutrition have a relationship with financial conditions. Good nutritional intake requires good food ingredients as well. Food ingredients that contain good nutrition have a tendency to be more expensive. Some of the strategies carried out by the mothers of the pregnant group are not changing the existing diet, but only changing the type of food with more nutritious ones. For example: if during most of the time you eat meatballs, then when you are pregnant meatballs are replaced with cheap fish. Unlike the group of pregnant women, the group of breastfeeding mothers adds a little expenditure specifically for nutrition. This is because they want better baby nutrition. Meanwhile, the group of mothers of under-fives clearly stated that there was a significant increase in family nutrition. As said by Ida's respondent:

“...yo jelas nambah pak biaya gawe mangan, biasane gawe nambah jajan e arek-arek..." (it's family expenses nutrition, it's usually spent for kids snacks ... ") 
This increase in expenditure is often not accompanied by an increase in family monthly income, following is the average increase in expenditure for respondents by category by category:

Table 3. cost spending in daily activities.

\begin{tabular}{|c|c|c|c|c|c|c|}
\hline $\begin{array}{l}\mathrm{N} \\
\mathrm{o}\end{array}$ & category & \multicolumn{5}{|c|}{$\begin{array}{l}\text { Average increase in expenditure per month by family based } \\
\text { on type of }\end{array}$} \\
\hline & & $\begin{array}{l}\text { Consumptio } \\
\mathrm{n}\end{array}$ & Health & $\begin{array}{l}\text { Educatio } \\
\mathrm{n}\end{array}$ & $\begin{array}{l}\text { Transportatio } \\
\mathrm{n}\end{array}$ & Other \\
\hline 1 & $\begin{array}{l}\text { Pregnant } \\
\text { Woman }\end{array}$ & $\begin{array}{l} \pm \mathrm{Rp} \\
350,000\end{array}$ & $\begin{array}{l} \pm \mathrm{Rp} . \\
200,00 \\
0\end{array}$ & Free & $\begin{array}{l} \pm \mathrm{Rp} . \\
125,000\end{array}$ & $\begin{array}{l} \pm \mathrm{Rp} . \\
420,00 \\
0\end{array}$ \\
\hline 2 & $\begin{array}{l}\text { Breastfeedin } \\
\mathrm{g}\end{array}$ & $\begin{array}{l} \pm \mathrm{Rp} \\
425,000\end{array}$ & $\begin{array}{l} \pm \mathrm{Rp} . \\
50,000\end{array}$ & Free & $\begin{array}{l} \pm \mathrm{Rp} \\
100,000\end{array}$ & $\begin{array}{l}\text { Rp. } \\
390,00 \\
0\end{array}$ \\
\hline 3 & $\begin{array}{l}\text { Toddler's } \\
\text { mother }\end{array}$ & $\begin{array}{l} \pm \mathrm{Rp} . \\
785,000\end{array}$ & $\begin{array}{l} \pm \mathrm{Rp} . \\
100,00 \\
0\end{array}$ & $\begin{array}{l} \pm \mathrm{Rp} \\
70.000\end{array}$ & $\begin{array}{l} \pm \text { USD } \\
125,000\end{array}$ & $\begin{array}{l} \pm \text { IDR } \\
310,00 \\
0\end{array}$ \\
\hline
\end{tabular}

Note: other expenses are for ceremonial / ritual ceremonies which are accumulated during one period

Based on the table above, group toddler's mother is the most affected in financial issues. To find solutions to these financial problems. Respondents of mothers from all categories have a strategy to anticipate it. This strategy is known as the local term "arisan" or collecting money in one group at a certain period periodically where later the money will be given to lucky recipients in turn so that all members have their share. In "arisan" is coordinated by one chairman or coordinator whose task is to collect, collect, record, and pay to members. This work is done voluntarily by women. As for the period of "gathering" and gathering, these women can weekly, fortnightly, monthly. The "arisan" has a philosophy similar to budgeting. But the budgeting model here is carried out in groups with the participation of all members.

The "arisan" provides savings services that are managed without involving banks. These local savings can later be used to save and borrow members if they need funds for several purposes such as traditional ceremonies to welcome pregnancy, birth, breastfeeding. The funds collected will be deposited by the coordinator. But usually there are not many unemployed funds in this "arisan" group. This is because the funds have already been allocated by the recipients. The prospective borrowers of their money must book, in an "Osing" community called "amprah", before they can borrow. If the queue is long in the booking, the coordinator will conduct a mild interview to the candidates. Priority scale will be given to channel the funds to the members who have already booked.

This planning model is very helpful in managing family finances. Unusual needs related to health problems during pregnancy, breastfeeding and toddlers will be overcome. The breadwinners are helped by planning models like this. The need for daily needs is also accommodated in this savings group. The use of fixed asset purchases is not permitted in this group. Some comments from the husbands regarding the role of "arisan" was conveyed by one of the respondents, Pak Bambang:

“...untung pak ono arisan, dadi pas butuh duit gawe slametan iso ditalangi disik. Misale gak ono arisan yo repot nggolek selangan pak...”

(fortunately, we are joining in the" arisan ", it can be bailed out. This will be difficult to lent if we don't join the" arisan "... )

The role of women in the society is very significant. They must have good financial management skills, of course they also must have the ability to regulate nutrition for the 
family. Good financial planning during pregnancy, breastfeeding and toddlers will be able to solve the problem of nutrition intake as well as financial problems. However, habits gathered during this gathering also often lead to conflict. This can be prevented by optimizing the coordinator's role in managing this process.

\section{Conclusion}

Financial management is one skill that must be owned by every family. this management role can be carried out by husband or wife. Limited financial capacity will have an impact on the ability to spend, including spending related to family nutrition intake. dietary trends that exist in "Osing" communities often override food nutrition factors. This is due to financial problems. In fact, nutritional needs from the time of pregnancy must be considered so that the baby will have good nutrition so that it can be a brilliant generation. Through good financial planning and utilizing local culture, a group of "arisan" is formed that is able to solve financial problems in order to prepare brilliant generations.

\section{References}

1. L.N. Yuliati, Journal of Consumer Sciences 1, 2, 28-42 (2016)

2. A.S. Mendari, S.S. Kewal, Jurnal Economia 9, 2, 130-140 (2013)

3. Badan Pusat Statistik (BPS), Sensus Ekonomi Nasional (2014)

4. R. Martini, Journal of Social Sciences 8, 1 (2009)

5. A. Subroto, Accountability Village fund management (case studies in villages in the Tlogomulyo sub-district, Temanggung District, Central Java in 2008) (Undip, Semarang, 2009) (to-be-published)

6. T. Kurrohman, Proceedings of the International Conference on Accounting Studies, UITM (2015)

7. J.M. Lexy, Qualitative Research Methodology (Remaja Rosdakarya, Bandung, 2010)

8. B. Bungin, Qualitative Research (Prenada meda group, Jakarta, 2007)

9. A. Susanti, R. Rusnoto, N. Asiyah, Jurnal Ilmu Keperawatan dan Kebidanan 4, 1 (2013)

10. S. Mintarsih, Profesi (Profesional Islam): Media Publikasi Penelitian 3, 27-34 (2008)

11. R. Handayani, Jurnal Endurance 2, 2, 217-224 (2017) 